\title{
Pemaafan (Forgiveness) Istri Terhadap Suami Pelaku Pelecehan Seksual Pada Anak
}

\author{
Fauzia Ramadhianty, Harry Theozard Fikri \\ Fakultas Psikologi, Universitas Putra Indonesia "YPTK" Padang, Indonesia \\ Email: fauziadhian@gmail.com, harrytheozard@yahoo.com
}

\begin{abstract}
The purpose of this study is to find out how the forgiveness of the wife (forgiveness) of the husband of the perpetrators of sexual abuse of children. The subjects of this study were two wives whose husbands were sexually abusing children. The research method used in this study is a qualitative research method with a phenomenological research design. Based on research by researchers carefully that two subjects forgive their husbands who sexually abuse children. In this study there are three aspects of forgiveness, namely 1) avoidance motivations, 2) revenge motivations, and 3) beneviolence motivations. From the research findings on both subjects, it was found that the aspects that caused forgiveness in both subjects were avoidance motivations, and beneviolence motivations. While from the aspect of revenge motivations, it is not the cause of the two subjects giving forgiveness to their husbands, because the feelings of love and love of the subject to their husbands are not what they used to be, and they choose to stay with their husbands because of their children and in-laws.
\end{abstract}

Keywords: forgiveness, wife, sexual harassment, child

\begin{abstract}
Abstrak
Tujuan dari penelitian ini adalah untuk mengetahui bagaimana gambaran pemaafan (forgiveness) istri terhadap suami pelaku pelecehan seksual terhadap anak. Subjek penelitian ini adalah dua orang istri yang suaminya pelaku pelecehan seksual terhadap anak. Metode penelitian yang digunakan dalam penelitian ini adalah metode penelitian kualitatif dengan desain penelitia fenomenologi. Berdasarkan penelitian yang peneliti teliti bahwa dua orang subjek memafkan suaminya yang melakukan pelecehan seksual terhadap anak. Pada penelitian ini ada tiga aspek pemaafan yaitu 1) aspek avoidance motivations, 2) aspek revenge motivations, dan 3) aspek beneviolence motivations. Dari hasil temuan penelitian pada kedua orang subjek, ditemukan bahwa aspek yang menjadi penyebab pemaafan pada kedua orang subjek adalah aspek avoidance motivations, dan aspek beneviolence motivations, sedangkan dari aspek revenge motivations bukan menjadi penyebab kedua subjek memberikan pemaafan kepada suaminya, karena perasaan sayang dan cinta subjek kepada suaminya sudah tidak seperti dulu lagi, dan mereka memilih untuk bertahan dengan suaminya karena anak dan mertua.
\end{abstract}

Kata kunci: pemaafan, istri, pelecehan seksual, anak

\section{Pendahuluan}

Perkawinan menjadi pondasi bagi keluarga, oleh karena itu ketika sepasang manusia menikah akan lahir keluarga yang baru. Keluarga merupakan unit sosial penting dalam bangunan masyarakat. Keluarga merupakan warisan umat manusia yang terus di pertahankan keberadaannya dan tidak lekang oleh perubahan zaman. Berbagai perubahan oleh faktor perkembangan zaman tentu saja memengaruhi corak dan karakteristik keluarga, namun substansi keluarga tidak terhapuskan (Lestari, 2018). Menurut Murdock (Lestari, 2018) keluarga merupakan kelompok sosial yang memiliki karakteristik tinggal bersama, terdapat kerja sama ekonomi, dan terjadi proses reproduksi. Sedangkan menurut Lestari (2018) keluarga adalah rumah tangga yang memiliki hubungan darah atau perkawinan atau menyediakan terselenggaranya fungsi-fungsi instrumental mendasar dan fungsi-fungsi ekspresif keluarga bagi para anggotanya yang berada dalam suatu jaringan. Islam menganjurkan umatnya untuk menikah karena mempunyai tujuan-tujuan yang ingin dicapai. Dibalik anjuran yang diperintahkan kepada umat manusia, pasti ada hikmahnya. Salah satu tujuan pernikahan seperti yang terdapat dalam surat Ar-Rum ayat 21 adalah untuk memperoleh kententeraman, kenyamanan, serta rasa kasih dan sayang. Untuk itulah kita dianjurkan menikah bagi yang sudah mampu (Zaini, 2015).

Adapun tujuan pernikahan yaitu mendapatkan dan melangsungkan keturunan. Naluri manusia adalah cenderung untuk mempunyai keturunan yang sah yang diakui oleh dirinya sendiri, masyarakat, negara dan kebenaran keyakinan agama Islam. Dan tujuan selanjutnya tentu saja adalah penyaluran kebutuhan seks dan penumpahan kasih sayang. Sudah menjadi kodrat iradah Allah SWT manusia diciptakan berjodoh-jodoh dan diciptakan oleh Allah SWT mempunyai keinginan untuk berhubungan seksual antara pria dan wanita. Pernikahan juga bertujuan untuk memelihara diri dari kerusakan.

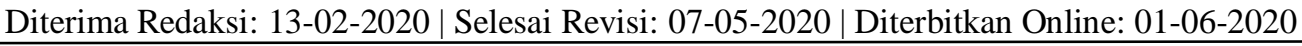


Orang-orang yang tidak melakukan penyaluran seks dengan pernikahan akan mengalami ketidakwajaran dan dapat menimbulkan kerusakan, entah kerusakan dirinya sendiri ataupun orang lain bahkan masyarakat, karena manusia memiliki nafsu, sedangkan nafsu itu condong untuk mengajak kepada perbuatan yang tidak baik. Dengan pernikahan akan mengurangi dorongan yang kuat atau dapat mengembalikan gejolak nafsu seksual (Zaini, 2015).

Saat ini banyaknya perilaku negatif dari seks, misalnya seks bebas baik karena suka sama suka maupun karena bayaran, serta adanya pelecehan seksual. Dewasa ini masyarakat sering dihadapi dengan kasus-kasus pelecehan seksual baik itu yang dialami oleh orang dewasa maupun anak-anak, dengan motif yang berbeda-beda (Bahri \& Fajriani, 2015).

Berdasarkan data dari Komnas Perempuan pada tahun 2016 di Indonesia sendiri kekerasan seksual berada diperingkat kedua terkait dengan kekerasan terhadap perempuan dengan jumlah kasus mencapai 2.399 kasus (72\%), pencabulan mencapai 601 kasus (18\%), dan pelecehan seksual mencapai 166 kasus (5\%) (Yudha \& Tobing, 2017). Menurut Solihin (dalam Fuadi, 2011) dalam penelitiannya dengan Yayasan Kesejahteraan Anak Indonesia melalui Center for tourism research and development Universitas Gadjah Mada melaporkan ditemukan sebanyak 3.969 kasus dengan rincian seksual abuse $65,8 \%$, physical abuse $19,6 \%$, emotional abuse $6,3 \%$, dan child neglech 8,3\%. Pelecehan seksual tidak hanya dilakukan oleh orang yang belum menikah, tapi juga banyak dilakukan oleh orang yang telah menikah. Dan bagi pelaku kekerasan seksual yang berstatus telah menikah, akan menimbulkan konflik dalam keluarganya. Sanksi yang akan diterimag berasal dari pasangannya, yaitu perceraian. Namun, tidak semua pasangan memilih perceraian sebagai sanksi dari perilaku tersebut, adalah sanksi hukum yang berlaku di Indonesia, dan juga sanksi yanada juga pasangan yang memilih untuk memberi pemaafan (forgiveness) terhadap kesalahan pasangannya.

Menurut Yudha \& Tobing (2017) pada umumnya pelecehan seksual atau pemerkosaan dilakukan oleh orang yang sudah sangat dikenal korban, misalnya teman dekat, kekasih, saudara, ayah (tiri maupun kandung), guru, pemuka agama maupun atasan. Sebagian kasus lainnya pelecehan seksual juga dilakukan oleh orang yang baru dikenal dan semula nampak sebagai orang baik-baik yang menawarkan bantuan. Pelecehan seksual tidak hanya dilakukan oleh orang yang telah menikah, namun juga banyak dilakukan oleh orang yang telah menikah. Dan bagi pelaku kekerasan seksual yang berstatus telah menikah, akan menimbulkan konflik dalam keluarganya. Sanksi yang akan diterima adalah sanksi hukum yang berlaku di Indonesia, dan juga sanksi yang berasal dari pasangannya, yaitu perceraian. Namun, tidak semua pasangan memilih perceraian sebagai sanksi dari perilaku tersebut, ada juga pasangan yang memilih untuk memberi pemaafan (forgiveness) terhadap kesalahan pasangannya.

Menurut McCullough dan koleganya (Lopez \& Snyder, 2003) pemaafan mencerminkan perubahan prososial dalam motivasi interpersonal yang seseorang alami, penurunan motivasi untuk menghindari kontak pribadi dan psikologis dengan pelaku, penurunan motivasi untuk membalas dendam atau melihat-lihat bahaya datang kepada pelanggar, dan peningkatan motivasi terhadap kebajikan. Menurut Snyder \& Thompson (Lopez \& Snyder, 2003) mendefenisikan pemaafan adalah membingkai pelanggaran yang dirasakan sedemikian rupa sehingga ikatan seseorang terhadap pelanggaranpelanggaran, dan gejala sisa dari pelanggaran hukum berubah dari negatif ke netral atau positif. Pemaafan mampu terjadi ketika individu mampu meredakan motivasi untuk menghindari pelaku dan motivasi untuk membalas dendam. Ketika individu memaafkan pasangannya maka akan terjadi peningkatan motivasi untuk berbuat baik atau benevolence motivation terhadap pasangan yang telah menyakiti (McCullough dalam Dewi \& Hartini, 2017).

Berdasarkan wawancara awal yang telah dilakukan peneliti dengan subjek pertama pada tanggal 25 Oktober 2019 dengan Inisial R yang berusia 37 tahun, diperoleh informasi bahwa R adalah seorang istri yang memaafkan suaminya yang melakukan pelecehan seksual terhadap anak. Suami R saat ini berada dalam penjara karena pelecehan yang dilakukannya kepada anak kelas tiga SD yang berusia delapan tahun. $\mathrm{R}$ masih mempertahankan rumah tangganya, karena $\mathrm{R}$ memikirkan dan mempertimbangkan permintaan mertua dan anak-anaknya. Berdasarkan wawancara awal yang peneliti lakukan dengan subjek kedua pada tanggal 08 September 2019 dengan inisial W yang berusia 32 tahun. Peneliti mendapatkan informasi bahwa $\mathrm{W}$ merupakan seorang istri yang suaminya melakukan pelecehan seksual terhadap anak, W mengatakan kalau korban dari perlakuan adalah anak perempuan berusia enam tahun yang merupakan anak tetangga W. Setelah kejadian ini W memaafkan suaminya 
dan masih mempertahankan rumah tangganya, karena menurut $\mathrm{W}$ kalau untuk berpisah $\mathrm{W}$ harus berfikir panjang terlebih dahulu.

\subsection{Pemaafan (forgiveness)}

Menurut McCullough (Dewi \& Hartini, 2017) forgiveness merupakan motivasi Menurut McCullough dan koleganya (Lopez \& Snyder, 2003) pemaafan mencerminkan perubahan prososial dalam motivasi interpersonal yang seseorang alami, penurunan motivasi untuk menghindari kontak pribadi dan psikologis dengan pelaku, penurunan motivasi untuk membalas dendam atau melihat-lihat bahaya datang kepada pelanggar, dan peningkatan motivasi terhadap kebajikan.Worthington (dalam Gani, 2011) menyatakan bahwa memaafkan adalah mengurangi atau membatasi kebencian serta dendam yang mengarah kepada pembalasan. Secara sederhana bisa dikatakan bahwa memaafkan lebih dari sekedar membuang hal-hal negatif. memaafkan juga menggerakan seseorang untukmerasakan kabaikan dari pelaku. dengan kata lain, memaafkan tidak hanya mengenyahkan emosi negatif tetapi juga menggerakan anda ke perasaan positif. Philpot (dalam Gani, 2011) menyatakan memaafkan sebagai proses (atau hasil dari proses) yang meliputi perubahan perasaan dan sikap terhadap pelaku. sejumlah peneliti memandangnya sebagai proses yang diniatkan dan disengaja, didorong oleh keputusan untuk memaafkan. hasil dari proses ini adalah menurunnya dorongan untuk mempertahankan perasaan tuntutan pelepasan emosi negatif kepada pelaku.

\subsection{Aspek-aspek Pemaafan (forgiveness)}

Menurut McCullough (Lopez \& Snyder. 2003), memaafkan dapat dibagi menjadi beberapa aspek, yaitu: (1) avoidance motivations yaitu penurunan motivasi untuk menghindari kontak pribadi dan psikologis dengan pelaku. Korban akan membuang keinginannya untuk menjaga jarak dengan orang yang telah menyakitinya (pelaku). Jadi, korban tidak menghindar ataupun menjauhi si pelaku, dia akan tetap berusaha menjaga hubungan yang dekat tersebut. (2) revenge motivations yaitu penurunan motivasi untuk membalas dendam atau melihat-lihat bahaya datang kepada pelanggar. Artinya, korban akan membuang keinginannya untuk membalas perbuatan yang telah dilakukan oleh pelaku. Korban akan berusaha meminimalisir rasa marah untuk membalas dendam kepada pelaku yang telah menyakitinya. (3) beneviolence motivations yaitu meningkatan motivasi untuk berbuat kebajikan dengan pelaku. Walaupun subjek merasa menjadi korban, akan tetapi subjek tetap ingin berbuat kebajikan kepada pelaku. Jadi subjek dalam situasi ini akan tetap menjaga hubungan agar tetap baik dengan pelaku.

\subsection{Pelecehan seksual}

Menurut Supardi \& Sadarjoen (Fajriani, 2015) Pelecehan seksual pada dasarnya adalah setiap bentuk perilaku yang memiliki muatan seksual yang dilakukan seseorang ataupun sejumlah orang, dan tidak disukai atau tidak diharapkan oleh korban sehingga menimbulkan akibat negatif pada korban, seperti: rasa malu, tersinggung, terhina, marah, kehilangan harga diri, kehilangan kesucian, dan sebagainya. Menurut Winarsunu (Utami, 2016), pelecehan seksual adalah segala macam bentuk perilaku yang berkonotasi seksual yang dilakukan secara sepihak dan tidak dikehendaki oleh korbannya. Bentuknya dapat berupa ucapan, tulisan, simbol, isyarat dan tindakan yang berkonotasi seksual. Aktifitas yang berkonotasi seksual bisa dianggap pelecehan seksual jika mengandung unsur-unsur sebagai berikut, yaitu adanya pemaksaan kehendak secara sepihak oleh pelaku, kejadian ditentukan oleh motivasi pelaku, kejadian tidak diinginkan korban, dan mengakibatkan penderitaan pada korban.

\section{Metode Penelitian}

Metode yang digunakan dalam penelitian ini adalah metode kualitatif. Metode penelitian kualitatif adalah metode penelitian yang berlandaskan pada filsafat postpositivisme, digunakan untuk meneliti pada kondisi objek yang alamiah, dimana peneliti adalah sebagai instrumen kunci, teknik pengumpulan data dilakukan secara triangulasi (gabungan), analisis data bersifat induktif/kualitatif, dan hasil penelitian kualitatif lebih menekankan makna dari pada generalisasi (Sugiono, 2014). Pendekatan yang digunakan pada penelitian ini adalah pendekatan fenomenologi. Menurut Polkinghorne (Herdiansyah, 2015) fenomenologi yaitu suatu studi untuk memberikan gambaran tentang suatu arti dari pengalaman-pengalaman beberapa individu mengenai suatu konsep tertentu. 
Dasar analisis data pada penelitian ini menggunakan analisis tematik (thematic analysis). Alasan peneliti menggunakan analisis tematik adalah untuk menemukan pola atau tema yang telah didapatkan pada data-data atau informasi-informasi pada tahap wawancara. Analisis tematik merupakan proses pengkodean informasi yang menghasilkan tema, model tema atau indikator kompleks berdasarkan fenomena yang diteliti (Poerwandari, dalam Leries, 2018). Peneliti menggunakan teknik purposive sampling dimana teknik proposive sampling adalah teknik penentuan sample dengan pertimbangan tertentu dengan membuat suatu pedoman karakteristik sampel guna mengambil subjek yang benarbenar memenuhi karakteristik penelitian (Sugiono, 2016). Adapun kriteria subjek dalam penelitian ini adalah (1) subjek yang berstatus sudah menikah (istri), (2) memiliki suami pelaku pelecehan seksual terhadap anak, (3) bersedia menjadi subjek penelitian, (4) subjek dapat berkomunikasi dengan baik. Jadi jumlah subjek dalam penelitian ini berjuamlah dua orang.

Dalam penelitian ini peneliti hanya menggunakan pengambilan data melalui wawancara. Menurut Moleong (Hardiansyah, 2015) wawancara adalah percakapan dengan maksud tertentu. Percakapan dilakukan oleh dua pihak, yaitu pewawancara yang mengajukan pertanyaan dan terwawancara yang memberikan jawaban atas pertanyaan tersebut. Steweart dan Cash (Hardiansyah, 2015) wawancara diartikan sebagai sebuah interaksi yang di dalamnya terdapat pertukaran atau berbagai aturan, tanggung jawab, perasaan, kepercayaan, motif, dan informasi. Wawancara bukanlah suatu kondisi satu orang melakukan atau memulai pembicaraan sementara yang lain hanya mendengarkan.

Teknik wawancara yang dilakukan dalam penelitian ini adalah wawancara langsung yaitu peneliti berhadapan langsung dengan subjek dan mengajukan pertanyaan yang bertujuan agar dapat memperoleh data-data yang di inginkan langsung dari subjek penelitian. Menurut Gorden (Hardiansyah, 2015) wawancara merupakan percakapan antara dua orang yang salah satunya bertujuan untuk menggali dan mendapatkan informasi untuk suatu tujuan tertentu. Wawancara yang dilakukan dalam penelitian ini adalah wawancara dengan pertanyaan terbuka (open endeed question) dan bersifat semi-terstruktur adalah pertanyaan terbuka yang berarti bahwa jawaban yang diberikan terwawancara tidak dibatasi, sehingga subjek dapat lebih bebas mengemukakan jawaban apa pun sepanjang tidak keluar dari konteks pembicaraan (Herdiansyah, 2015).

Penelitian yang digunakan adalah penelitian kualitatif dengan pendekatan fenomenologis, yang dimaksudkanmemberikan gambaran tentang suatu arti dari pengalaman-pengalaman beberapa individu mengenai suatu konsep tertentu. (1) Lokasi penelitian : Penelitian ini dilakukan pada subjek yang suaminya melakukan pelecehan seksual terhadap anak. (2) Perkiraan jumlah subjek penelitian : Jumlah subjek penelitian dalam penelitian ini adalah dua orang. (3) Waktu penelitian : Penelitian ini dilakukan dari bulan Agustus 2019 hingga bulan Januari 2020. (4) Tahap-tahap wawancara

Adapun tahap-tahap pelaksanaan wawancara dalam penelitian ini sebagai berikut: (a) Menetapkan masalah yang akan di teliti (b) Menghubungi calon subjek yang sesuai dengan karakteristik penelitian.(c) Meminta kesediaan subjek untuk melakuakan wawancara. (d) Membuat kesepakatan dengan subjek mengenai waktu dan tempat wawancara diadakan. (e) Memastikan semua perlengkapan wawancara yang dibutuhkan, seperti alat tulis, dan pedoman wawancara yang kesemuanya dalam kondisi baik serta lenbaran observasi untuk mencatat situasi dan kondisi responden pada saat wawancara.

\section{Hasil dan Pembahasan}

Berdasarkan hasil temuan peneliti yang telah dipaparkan pada bab sebelumnya terhadap subjek penelitian, diperoleh jawaban yang mengungkapkan tentang gambaran Pemaafan (forgiveness) istri terhadap suami pelaku pelecehan seksual pada anak bahwa kedua subjek dalam penelitian ini memaafkan suaminya yang melakukan pelecehan seksual pada anak. Menurut McCullough (dalam Lopez \& Snyder, 2003), memaafkan dapat dibagi menjadi beberapa aspek, yaitu avoidance motivations, revenge motivations, dan beneviolence motivations. Berikut hasil penelitian dari kedua subjek penelitian berdasarkan teori McCullough (dalam Lopez \& Snyder, 2003).

Tabel 1. Aspek - aspek pemaafan (forgiveness) pada subjek I dan subjek II

\begin{tabular}{cccc}
\hline \multirow{2}{*}{ Subjek } & \multicolumn{3}{c}{ Pemaafan (forgiveness) } \\
\cline { 2 - 4 } & Avoidance Motivations & Revenge Motivations & Beneviolence Motivations \\
\hline I & $\checkmark$ & - & $\checkmark$ \\
\hline \multicolumn{4}{c}{226}
\end{tabular}


Keterangan:

$\checkmark \quad$ : Sebagai Penyebab

- $\quad$ : Bukan Sebagai Penyebab

Berdasarkan hasil temuan penenlitian yang telah dipaparkan diatas, ditemukan bahwa aspek pemaafan (forgiveness) pada subjek I dan II adalah aspek avoidance motivations dan beneviolence motivations, sedangkan yang bukan aspek pemaafan (forgiveness) adalah revenge motivations.

\subsection{Pembahasan}

Berdasarkan hasil temuan penenlitian yang telah dipaparkan sebelumnya, ditemukan bahwa aspek pemaafan (forgiveness) pada subjek I dan II adalah aspek avoidance motivations dan beneviolence motivations, sedangkan yang bukan aspek pemaafan (forgiveness) adalah revenge motivations. Menurut McCullough dan koleganya (Lopez \& Snyder, 2003) pemaafan mencerminkan perubahan prososial dalam motivasi interpersonal yang seseorang alami, penurunan motivasi untuk menghindari kontak pribadi dan psikologis dengan pelaku, penurunan motivasi untuk membalas dendam atau melihat-lihat bahaya datang kepada pelanggar, dan peningkatan motivasi terhadap kebajikan.

Menurut Enright (dalam, Nashori 2011) mendefenisikan pemaafan sebagai kesediaan seseorang untuk meninggalkan memarahan, penilaian negatif, dan perilaku acuh tidak acuh terhadap orang lain yang telah menyakitinya secara tidak adil, pada sisi lain menumbuhkan perasaan iba, kasih sayang, dan kemurahan hati terhadap orang yang telah menyakiti hatinya tersebut. Menurut Philpot (dalam Gani, 2011) menyatakan memaafkan sebagai proses (atau hasil dari proses) yang meliputi perubahan perasaan dan sikap terhadap pelaku. Sejumlah peneliti memandangnya sebagai proses yang diniatkan dan disengaja, didorong oleh keputusan untuk memaafkan. Hasil dari proses ini adalah menurunnya dorongan untuk mempertahankan perasaan tuntutan pelepasan emosi negatif kepada pelaku.

Berdasarkan hasil penelitian, dari temuan yang didapatkan peneliti terkait (1) Avoidance motivations, pada subjek I, subjek selalu menemani suaminya saat proses pengadilan karena subjek ingin mengetahui jalannya persidangan dan bagaimana hasil persidangan tersebut, setelah suami subjek dijatuhi hukuman subjek selalu menunjungi suaminya sekali seminggu dan terkadang dua kali seminggu, saat berkunjung subjek dan suaminya banyak membahas tentang anak. Sedangkan subjek II, juga selalu menemani suaminya saat proses pengadilan, subjek pertama kali mengunjungi suaminya pada ke esokan hari setelah suami subjek dibawa ke POLSEK karena subjek ingin mengetahui keadaan suaminya. subjek mengunjungi suaminya karena itu adalah suaminya dan ayah anaknya. Worthington (dalam Gani, 2011) menyatakan bahwa memaafkan adalah mengurangi atau membatasi kebencian serta dendam yang mengarah kepada pembalasan. Secara sederhana bisa dikatakan bahwa memaafkan lebih dari sekedar membuang hal-hal negatif. memaafkan juga menggerakan seseorang untukmerasakan kabaikan dari pelaku. dengan kata lain, memaafkan tidak hanya mengenyahkan emosi negatif tetapi juga menggerakan anda ke perasaan positif. Menurut Root (dalam Utami, 2012) avoidance motivations yaitu menurunnya motivasi individu untuk menghindari orang yang menyakiti yang ditandai dengan membuang keinginan untuk menjaga jarak dari prilaku yang dinilai telah menyakiti dan individu menarik diri dari orang yang telah menyakitinya. (2) revenge motivations, pada subjek I dan II aspek revenge motivations bukan sebagai penyebab pemaafan (forgiveness. (3) Beneviolence motivations, pada subjek I, subjek menunjukan perhatian kepada suaminya dengan cara membawakan makanan dan kue yang disukai suaminya, subjek merasa kasihan melihat suaminya didalam penjara karena tidak bisa beraktivitas dengan bebas seperti biasa, subjek juga merindukan keluarganya berkumpul kembali. Sedangkan pada subjek II memberikan perhatian kepada suaminya dengan cara mendengarkan keluh kesahnya. Saat berkunjung subjek membicarakan tentang anak dan hal-hal yang akan membuat tertawa agar suaminya melupakan masalahnya. Saat dekat dengan suaminya subjek merasa sedih dan kasihan kepada suaminya, dan juga teringat anaknya yang jauh dari ayahnya. Menurut Snyder \& Thompson (dalam Lopez \& Snyder, 2003) mendefenisikan pemaafan adalah membingkai pelanggaran yang dirasakan sedemikian rupa sehingga ikatan seseorang terhadap pelanggaran-pelanggaran, dan gejala sisa dari pelanggaran hukum berubah dari negatif ke netral atau positif. Menurut Cohen (dalam Utami, 2012) beneviolence motivations yaitu adanya dorongan untuk berbuat baik terhadap orang yang menyakitinya, dengan mulai berempati dan berkomunikasi dengan baik, niat baik ini dapat dicapai. 


\section{Kesimpulan}

Berdasarkan hasil penelitian dan pembahasan yang telah peneliti uraikan pada bab sebelumnya, maka dapat ditarik kesimpulan bahwa dua subjek dalam penelitian ini memiliki pemaafan (forgiveness) kepada suaminya yang melakukan pelecehan seksual terhadap anak. Adapun aspek-aspek pemaafan (forgiveness) adalah: (1) Aspek pemaafan (forgiveness) terhadap kedua subjek adalah aspek avoidance motivations dan beneviolence motivations. (2) Aspek yang tidak menjadi penyebab pemaafan (forgiveness) terhadap kedua subjek adalah aspek revenge motivations .

\section{Daftar Rujukan}

American Psychological Association. (2003). Positive Psychological Assessment: A handbook of Models and Measures. Washington, DC: Lopez, Snyder

Bahri, Fajriani. (2015). Suatu Kajian Awal Terhadap Tingkat Pelecehan Sexual di Aceh. Jurnal Pencerahan. Volume 9, No.1.

Dewi, Hartini. (2017). Dinamika Forgiveness Pada Istri yang Mengalami Kekerasan dalam Rumah tangga (KDRT). Jurnal Psikologi dan Kesehatan Mental. Volume 2, No.1.

Fuadi. (2011). Dinamika Psikologis Kekerasan Seksual: Sebuah Studi Fenomenologi. Jurnal Psikologi Islam. Volume 8, No.2.

Gani. (2010). Forgiveness Therapy: Maafkanlah Niscaya Dadamu Lapang. Jakarta: Kanisius.

Herdiansyah. (2015). Metodologi Penelitian Kualitatif untuk Ilmi Psikologi. Jakarta: Salemba Empat.

Lestari. (2018). Psikologi Keluarga. Jakarta: Kencana.

Nashori. (2011). Meningkatkan Kualitas Hidup Dengan Pemaafan. Jurnal Psikologi dan Ilmu Sosial Budaya UII. Volume 33, No 75 .

Poerwandari. (2000). Kekerasan terhadap perempuan: Tinjauan psikologi feministik, dalam Sudiarti Luhulima "Pemahaman Bentuk-bentuk tindak kekerasan terhadap perempuan dan alternative pemecahannya", Jakarta: Kelompok kerja "convention watch".

Septeria. (2012). Hubungan Antara Harga Diri (self esteern) Dengan Memaafkan (forgiveness) Pada Remaja Putri di SMA Islam Al Maarif Singosari Malang. Skripsi Sarjana, Fakultas Psikologi UIN Maliki, Malang.

Sisca \& Moningka. (2009). Resiliensi Perempuan Dewasa Muda yang Pernah Mengalami Kekerasan Seksual di Masa Kanak-kanak. Jurnal Proceeding PESAT (Psikologi, Ekonomi, Sastra, Arsitektur \& Sipil). Volume: 3 Oktober 2009.

Sugiono. (2017). Metode Penelitian Kuantitatif Kualitatif dan R\&D. Bandung: Alfabeta.

Synder, C.R. \& Lopez, S.J. (2002). Handbook of Positive Psychology. New York: Oxford University Press.

Yudha, Tobing. (2017). Dinamika Memaafkan Pada Korban Pelecehan Seksual. Jurnal Psikologi Udayana. Volume 4, No.2.

Zaini. (2015). Membentuk Keluarga Sakinah Melalui Bimbingan dan Konseling Pernikahan. Jurnal Bimbingan Konseling Islam. Volume 6, No.1. 